\title{
A NOTE ON THE ORIGIN AND HISTOGENESIS OF THE MESONEPHRIC DUCT IN MAMMALS
}

\author{
ERNST WEINBERG
}

Tartu (Dorpat), Esthonia, and Department of Anatomy, University of Michigan

THREE FIGURES

The histogenesis of the primary excretory duct (the pronephric, mesonephric, or wolffian duct) has been a question of controversy. The majority of authors (Waldeyer, '70; Romiti, '73; Kowalewsky, '75; Koelliker, '76; Renson, '83; Meyer, '90, and many others) agree that the mesonephric or wolffian duct is derived from the mesoderm. According to Romiti ('73), the duct originates in chick embryos as an evagination of the pleuroperitoneal cavity. This evagination subsequently is cut off from this cavity and is constricted into a duct. Kowalewsky ('75) derives the duct from an evagination of the dorsal lamina of the intermediate cell mass, the latter being provided with a cavity communicating with the coelom and the somitic cavity. According to Gasser ('77) and Sedgwick ('81), the cephalic portion of the mesonephric duct of chick embryos develops from the intermediate cell mass and then grows freely caudalward, without having any direct connection with the intermediate cell mass below its point of origin. These authors, as well as Waldeyer ('70), Balfour ('81), and Mihalkovicz ('85), in contradistinction to Romiti and Kowalewsky, considered the duct as an originally solid rod of cells, which only later becomes provided with a lumen. His ('65) at first regarded the mesonephric duct of the chick as derived from a thickened fold of the ectoderm, by the side of the neural fold. Later ('68), His withdrew this statement, which, however, has been adopted by Hensen 
('67) and Graf' Spee ('83) for mammals. Graf Spee considered that the anlage of the mesonephric duct lay in that part of the ectoderm which is opposite the intermediate cell mass. Here, according to this author, the ectoderm forms in the caudal portion of the embryo a definite thickening of limited extent. This thickening was thought to separate cephalad into the ectoderm proper and the anlage of the mesonephric duct. Still farther cephalad, the duct was thought to separate entirely from the ectoderm and to enter into close contact with the intermediate cell mass. According to Hertwig ('10) and Meyer ('90), the cephalic portion of the primary excretory duct develops from the mesoderm. Caudalward, the duct separates from its parent tissue and fuses with the ectoderm. In Meyer's human embryo (of $4.25 \mathrm{~mm}$.) the duct in its most caudal portion is again free from a comnection with the ectoderm. According to Hertwig, there is a possibility that in mammals the ectoderm may contribute to the development of the caudal portion of the duct. Felix ('04) believed that in mammals a longitudinal growth of the duct occurs, in which the ectoderm participates. However, no participation of the ectoderm in the formation of the mesonephric duct is admitted by Hertwig and Felix in bony fishes.

The studies of MacCallum ('02) and Gage ('05) have shown that the excretory duct consists, in human embryos at early stages of development, of a frontal and a caudal portion, which are separated from each other by a marked interval. These authors are inclined to consider the frontal portion of the duct as related to the homologue of the pronephros of lower forms, since its anterior extremity opens directly into the coelom, being "evidently a direct turning in of the lining of the coelom" (MacCallum). In the embryo of MacCallum the frontal portion of the excretory duct lies opposite the sixth to the ninth myotomes, while the caudal portion begins at the level of the tenth myotome and extends caudad to the level of the last (nineteenth) myotome. In the Gage embryo the presumed pronephric tubule lies at the level of the eleventh myotome. 
Our own observations pertain to a study of a series of mammalian embryos from the Embryological Collection of the Department of Anatomy, University of Michigan, and particularly of series of guinea-pig and rabbit embryos of early stages of development. Their study has led to the general conclusion that the mesonephric duet is histogenetically derived from the intermediate cell mass of the mesoderm and acquires only secondarily in its caudal portion a close contact with the ectoderm. Three especially pertinent series are here particularly referred to: two guinea-pig and one rabbit series, since they afforded critical and favorable material bearing on the problem under consideration. Abundant other series, here not especially referred to, of preceding and succeeding stages were available.

In a guinea-pig embryo removed from the uterus fourteon days sixteen hours after insemination, in which fourteen somites are distinguishable, we can observe at the level of the twelfth to the fourteenth somites a more or less clearly delimited rod of cells lying dorsal to the intermediate ce'l mass. This cell rod is without lumen and is regarded as the anlage of the mesonephric duct. It is fused definitely in its frontal portion with the intermediate cell mass, while its narrower caudal portion enters into a close relationship with the ectoderm. In this embryo there is no trace of any structures which might be considered as the homologue of the pronephric tubules.

The embryo, after careful fixation, was cut serially in crosssections of $7 \mu$ thickness, stained in hematoxylin and Congo red. The series embraces 635 sections, numbering from the frontal pole of the embryonic shield to the caudal limit of the allantois. Of the fourteen somites determined, neither the first nor the last somite is provided with a cavity, such as is present in the other somites. The neural groove is found closed and forms a tubular structure from the level of the $32 \mathrm{nd}$ to the level of the 394th section, i.e., corresponding in general to the level at which the somitic segmentation is no longer evident. In certain sections the ganglion of the fifth 
nerve is cut off from the surface ectoderm and the neural groove, and lies lateral to the latter. The notochord in its most frontal part is in close contact with the entoderm of the foregut. It becomes entirely separated from the entoderm at the level of the second somite. It lies then in close relation to the neural tube ventrally. The first somite on the one side makes its appearance in the 117 th section and on the other side in the 134th section.

The intermediate cell mass becomes distinguishable at the level of the sixth somite. The medial half of the dorsal aorta lies, at this level, in close relation to the ventral portion of the somite. Just lateral to the aorta lies the coelomic cavity, which is narrow in the mediolateral and larger in the dorsoventral plane and extends thus dorsalward and ventralward to the level of the aorta. The intermediate cell mass is often continuous with the somites medially and with the wall of the coelomic cavity laterally. The nuclei of the intermediate cells are, in general, more round than those of the cells of the coelomic wall. They are of a more distinct outline than are the nuclei of either the coelomic or the somitic mesodermal cells and the granulations are sharper in the former than in both the latter. Mitotic figures are frequently met with in the intermediate cell mass. In the region under consideration, the ectoderm forms a relatively thin, outwardly concave fold opposite the intermediate cell mass. It appears here slightly thickened. The apparent thickening is probably due, in part at least, to the orientation of the longer axis of the ectodermal cells to the plane of the section. Sometimes the nuclei of the ectodermal cells forming the fold are not arranged in a perfectly regular row. At the level of the sixth and seventh somites the intermediate cell mass is very small. It disappears almost entirely at the intervals between the somites. At the level of the eighth somite the intermediate cell mass becomes more distinct, extending from the coelomic to the somitic mesoderm, in close relation dorsally to the lateral half of the aorta. In cross-sections it appears large in its middle portion, while the cell bridges, which connect it 
with the somite medially and the coelomic wall laterally, are usually relatively narrow. The large middle part of the intermediate cell mass extends dorsally toward the ectoderm; however, it does not come in contact with the latter. Approximately at the level of the middle of the eighth somite the long axes of the cells of the intermediate cell mass on the one side are arranged radially around the center of the cell mass; in the center a small cavity is to be noted. The cell nuclei are situated at the periphery of the cells, at the pole opposite to the center of the cell mass. At the level of the caudal end of the eighth somite the intermediate cell mass becomes small, but it does not disappear entirely even at the place opposite the interval between the somites. The intermediate cell mass is again more pronounced at the beginning of the ninth somite, but only for a few sections, after which it again becomes smaller. At the level of the ninth somite the intermediate cell mass is narrower in both the dorsoventral and the mediolateral planes than at the level of the eighth somite. At the level of the tenth somite the intermediate cell mass appears as a quite dense band of cells between the somite and the coelomic wall and continuous with both of these.

At the level of the caudal portion of the tenth somite a bud is given off from the intermediate cell mass dorsalward, while this latter mass is, as before, connected with the coelomic and somitic mesoderm, chiefly with the former. At the level of the eleventh somite, this dorsal bud closely approaches the ectoderm. In cross-sections the bud presents a somewhat quadrangular form. The ventromedial side of the quadrangle is continuous with the intermediate cell mass, the dorsolateral side is parallel to the ectoderm and lies, as mentioned before, quite close to the latter. A shallow fold in the ectoderm at this level has its concavity directed inward, while in more frontal regions the concavity of the fold at relatively the same region is directed outward. The ectoderm is somewhat flattened in the region where the bud of the intermediate cell mass comes into contact with it. In some sections the whole intermediate cell mass has the form of 
a quadrangle, which is extended from the aorta to the ectoderm and which is connected on both sides with the coelomic and somitic mesoderm by small cell bridges. At the level of the twelf th somite the dorsal bud of the intermediate cell mass takes on a more nearly rounded outline (fig. 1, right side).

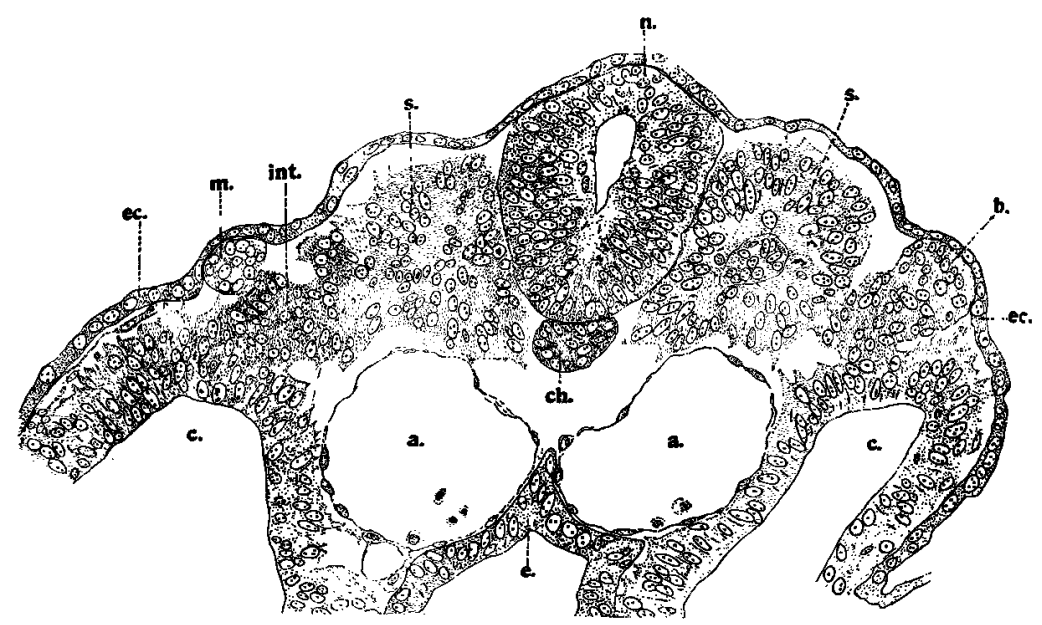

Fig. 1 Cross-section through the level of the twelfth sornite of a guinea-pig cmbryo of fourteen somites. Camera-lucida drawing. $\times 182$. The right side of the figure is slightly more frontal (middle of the twelfth somite) than the left (caudal portion of the twelfth somite). On the right side the intermediate cell mass gives off a bud $(b$.), which lies close to the ectoderm. On the left side this bud is already well delimited from the intermediate cell mass and recognizable as the anlage of the mesonephric duct. $a$., aorta; $b$., bud of the intermediate cell mass continuing eaudad into the mesonephric duet; c., coelow; ch. notochord; $e_{\text {., }}$ entoderm; $c c$., ectoderm; int., intermediate cell mass; $m$. . mesomephric duet; n., neural tube; s., somite.

It becomes more clearly delimited from the rest of the intermediate cell mass, though it is still, in the main, connected with the latter on the ventromedial side. The dorsolateral side is here in a still closer contact with the ectoderm. The intermediate cell mass, as before, is stretched out between the coelomic and somitic mesoderm. The bud differs from the rest of the intermediate cell mass by reason of its greater compactness. In general, its cells stain somewhat paler than tbose of the latter. The cells of the bud differ from the ecto- 
dermal elements in their staining reaction as well as in the shape of their nuclei. The nuclei of the ectodermal cells are often more elongated, their long axes being directed in a transverse plane, while the cell nuclei of the bud are, in general, more nearly round and with a somewhat sharper outline. Farther caudalward, but still at the level of the twelfth somite, the bud assumes a somewhat oval shape on one side. Its long axis is oriented in a transverse plane, the medial pole being more dorsal in position than the lateral. On the other side the bud remains more nearly round. In certain sections it is now quite clearly delimited from the rest of the intermediate cell mass. In some places only a small part of its ventromedial surface is continuous with the latter (fig. 1, left side). The nuclei of the intermediate cell mass are more elongated in this region, which is related to the coelomic mesoderm. Mitotic figures are often seen in the intermediate cell mass adjacent to the round or oval bud. The ectoderm forms, as before, an inwardly concave fold over the dorsolateral surface of the bud and lies in close contact with this surface. In certain sections through the level of the twelfth somite the bud of the intermediate cell mass is already recognizable as the anlage of the mesonephric duct, differentiating from the intermediate cell mass; it becomes entirely separated from this mass at the level of the thirteenth somite. The bud is smaller in size than the bud of the intermediate cell mass, of which it represents thus the caudal continuation. It is composed of from six to eight cells arranged in a round or oval mass without lumen and lying in close contact with the ectoderm dorsolaterally and with the intermediate cell mass ventromedially. The nuclei and the protoplasm of the cells composing the mesonephric duct, like those of the cells of the more frontally situated bud of the intermediate cell mass, appear somewhat paler than the elements of the intermediate cell mass. Their staining reaction is to a certain degree different from that of the ectodermal cells-in hematoxylin-Congo red preparations they present a somewhat more pink color than the latter, which are of a slightly more 
grayish tone. The nuclei of the cells of the mesonephric duct are nearly round, in contradistinction to the more elongated nuclei of the ectodermal cells. Farther caudalward the mesonephric duct becomes smaller and smaller. It is more fused with the ectoderm near the level at which the delimitation of the thirteenth somite from the fourteenth somite is indicated. At the level of the frontal portion of the fourteenth somite the mesonephric duct is represented in each cross-

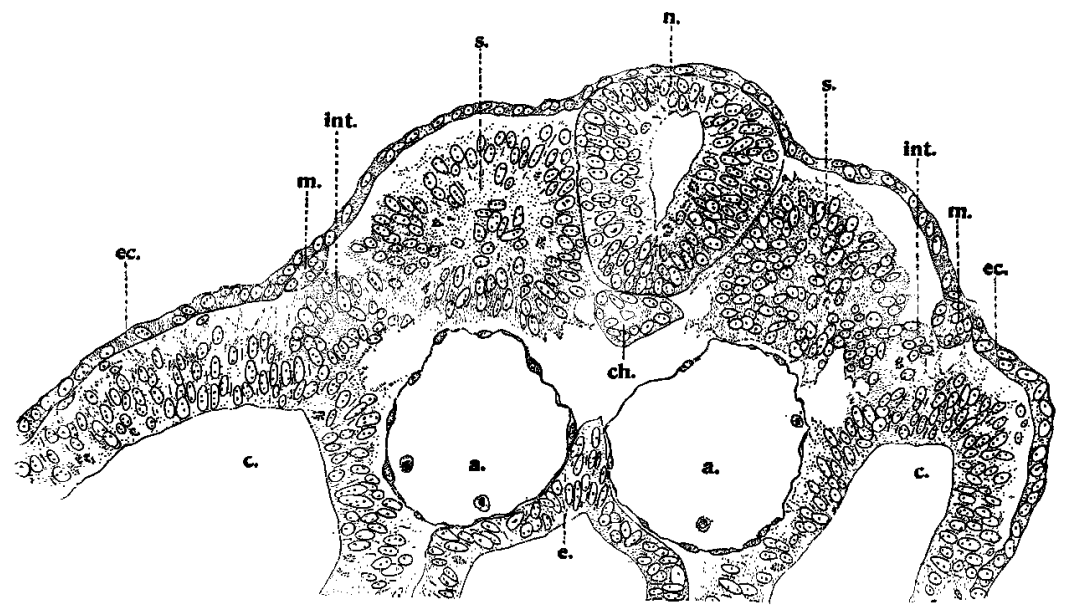

Fig. 2 Cross-section through the level of the fourteenth somite of the same embryo from which figure 1 was drawn. The right side of the figure is farther frontal than the left. Camera-lucida drawing. $\times 182$. a., aorta; c, coelom; ch.. notochord; e., entoderm; ec., ectoderm; int., intermediate cell mass; $m$. , mesonephrie duet; n., neural tube; s., somite.

section by only two or three cells, which adhere to the ectoderm. These cells are here entirely separated from the ventromedially lying intermediate cell mass. In their staining reaction they approach more nearly the mesodermal than the ectodermal elements. In general, also, the juxtaposed cell boundaries between the ectoderm and the mesonephric duct are more distinct than those between the elements of the duct itself or of the ectoderm. In certain sections the mesonephric duct is still composed of more than two or three cells (fig. 2). In such sections these are sometimes arranged into a 
very short band situated parallel and close to the ectoderm. The duct disappears entirely at the level of the fourteenth somite. Until its caudal limit is reached, it is in very close contact with the ectodermal elements. The intermediate cell mass is here present as a short strip between the coelomic and somitic mesoderm, dorsal to the aorta. Candalward the intermediate mesoderm becomes undifferentiable.

Thus, even in its most caudal part the mesonephric duct is distinguishable from the ectoderm by the different staining reaction of its elements and by a usually more or less distinct line of delimitation between both structures, which line is indicated by their cell boundaries. Such a differentiation can be made in spite of the fact that an occasional overlapping (fig. 2, right side), dependent on the plane of the section, might sometimes simulate a closer fusion than is actually present. The ectoderm forms a fold and sometimes a certain thickening at the place which corresponds to the intermediate cell mass. However, the thickening is more pronounced in regions where the duct is not yet differentiable from the intermediate cell mass. In more caudal regions, where the duct lies closer to the ectoderm, the latter is rather flattened at the place of contact.

In another guinea-pig embryo taken fourteen days sixteen and one-half hours after insemination, but of an earlier stage of development (eleven somites), the mesonephric duct is more or less delimited from the intermediate cell mass, but only for a relatively few sections. This embryo, after careful fixation, was cut in nearly transverse sections of $7 \mu$ thickness and stained with hematoxylin and Congo red. The series includes 511 sections from the frontal end of the embryonic shield to the caudal end of the allantois. The intermediate cell mass, for the greater part, is continuous with the coelomic mesoderm and the somites, as in the embryo previously noted. At the level of the eighth to the eleventh somites the intermediate cell mass forms a dorsal bud of a round or sometimes more nearly quadrangular shape. This bud enters into close contact with the ectoderm. At the level of the 
frontal end of the bud the coelomic wall forms a shallow groove at the place which corresponds to the intermediate cell mass. However, the groove is present for only a very short distance. The bud of the intermediate cell mass represents only in a few occasional sections a more compact round or oval cell mass without lumen, which is more or less distinctly delimited from the intermediate cell mass. In sections where this occurs it can be identified as the anlage of the mesonephric duct. Its caudal and frontal limit continues into the bud of the intermediate cell mass. The ectoderm forms, as in the former embryo, a shallow fold at some places over the intermediate cell mass. Occasionally it appears thicker in these places.

In our series of early-stage rabbit embryos the origin of the mesonephrie duct from the mesoderm and its primary independence of the ectoderm are also very evident. The description of the anlage of the duct in a rabbit embryo of fourteen somites follows. The embryo was fixed in Bouin's fluid, cut in serial cross-sections of $10 \mu$ thickness, and stained in iron-lac-hematoxylin. The series includes 373 sections from the frontal end of the embryonic shield to the caudal end of the allantois. The neural groove is closed through the greater part of its extent, except for a short distance in its most caudal portion. At the level of the seventh to the tenth somites the intermediate cell mass is seen to be differentiating from the dorsomedial wall of the coelomic cavity. This cell mass is sometimes closely connected with the coelomic wall; sometimes it is of a more nearly round shape and related to the coelom by a narrow band of cells, so that the whole structure has the appearance of a club (fig. 3, left side). In certain sections the intermediate cell mass is quite independent of the coelomic mesoderm. In certain sections the pleuroperitoneal wall reveals a shallow groove at the place of its connection with the intermediate cell mass. Occasionally this groove continues farther into the latter cell mass as a narrow canal (fig. 3, right side). Such grooves and canals communicating directly with the coelomic cavity may 
be considered as the homologue of the rudimentary pronephric tubules.

At the level of the eleventh somite the intermediate mesoderm is often free from a connection with the pleuroperitoneal wall; sometimes related to it only by a narrow cell bridge. Usually no connection with the somites is observable.

At the level of the twelfth somite a more nearly round cell mass becomes delimited from the dorsal portion of the intermediate mesoderm. This round cell mass is considered as the anlage of the mesonephric duct. It is entirely separated from

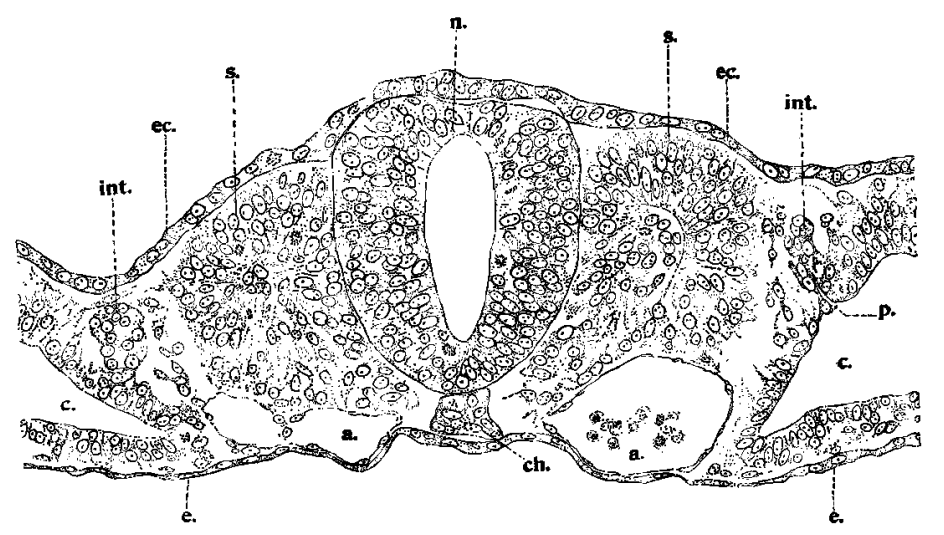

Fig. 3 Cross-section through the level of the ninth somite of a rabbit embryo of fourteen somites. Camera-lucida drawing. $\times 182$. a., aorta; c., coelom; ch., notochord; e., entoderm; ec., ectoderm; int.; intermediate cell mass; $n$., neural tube; $p$., homologue of a rudimentary pronephric tubule; s., somite.

the intermediate mesoderm at the level of the caudal end of the twelfth somite; in certain sections it is provided with a small lumen. The intermediate cell mass is here usually not connected either with the somitic or with the coelomic mesoderm, though its ventrolateral angle lies very close to the latter. At the level of the thirteenth somite the intermediate cell mass is connected with the coelomic wall and sometimes also with the somite. The mesonephric duct becomes smaller and lies now nearer to the ectoderm, which forms an outwardly concave fold at the corresponding place. The lumen of the duct is very clear. At the level of the caudal portion 
of the thirteenth somite the intermediate cell mass is connected with both the coelomic and the somitic mesoderm. At the level of the fourteenth somite the intermediate cell mass appears in the form of a band of cells stretched out between the somite and the coelomic wall. The mesonephric duct becomes smaller and loses its lumen. However, it continues a little farther caudad than the level of the fourteenth somite, disappearing sooner on one side than on the other. The caudal end of the duct lies quite close to the ectoderm, as in the above-described guinea-pig embryo of fourteen somites. However, a delimitation from the ectoderm is made very easily in the rabbit embryo. In the rabbit embryo the hasement membrane (membrana prima) of the ectoderm is often interrupted at places where the mesonephric duct lies near the ectoderm. It appears that sometimes, instead of lying. close to the latter, the membrane withdraws from it slightly at these places and lies at the side of the mesonephric duct adjacent to the ectoderm or even seems to be fused with the mesonephric duct, while a small space may be present between the duct and the ectodermal cells. Graf Spee described a basement membrane on that side of the mesonephric duet which faces the intermediate cell mass. Such a condition is not observable in our material.

In the rabbit embryo of fourteen somites, as in the guineapig embryo of the same number of somites, the mesonephric duct is recognizable at the level of the twelfth to the fourteenth somites. In both embryos the duct is fused in its frontal portion with the intermediate cell mass and differentiates as a bud of the latter. Caudally, the mesonephric duct separates from the intermediate cell mass; it becomes smaller and lies very close to the ectoderm. However, in both embryos the elements of the mesonephric duct are always differentiable from those of the ectoderm. In the rabbit embryo, also, rudimentary homologues of the pronephric tubules may be identified at levels frontal to the mesonephric duct. The intermediate cell mass in the rabbit embryo is continuous in its frontal part with the coelomic wall, but usually free from any connection with the somites. 
I wish to express my appreciation to Professor Huber for suggesting this study, for the privilege of using his embryological material, and for his direction of the work.

\section{SUMMARY}

The mesonephric duct differentiates in guinea-pig and rabbit from the intermediate cell mass of the mesoderm. It makes its appearance as a solid rod of cells, which at its caudal end lies very close to the ectoderm. Especially in its caudal portion, it is often continuous with the somitic mesoderm.

The material studied by us does not supply any evidence for the assumption of a histogenetic participation of the ectoderm in the development of the primary excretory duct in mammals.

\section{LITERATURE CITED}

BALFOUR, F. M. 1881 A treatise on comparative embryology, vol. 2. London. Feulx 1904 Die Entwickelung des Harnapparates. In Hertwig's Handbuch d. vergl. u. exp. Entwg. d. Wirbeltiere, Bd. 3, Teil 1, Kap. 2.

GaGE, S. PH. 1905 A three weeks human embryo, with especial reference to the brain and the nephric system. Am. Jour. Anat., vol. 4, p. 409.

Gasser, E. 1877 Beobathtungen über dio Entstehung des Wolff'schen Ganges bei Embryonen von Hühnern und Gänsen. Arch. f. mikr. Anat., Bd. 14, S. 442.

Hensex, V. 1867 Embryologische Mitteilungen. Areh. f. mikr. Anat., Bd. 3, S. 500 .

Hertwia, O. 1910 Lehrbuch der Entwicklungsgeschiehte des Menschen und der Wirbeltiere. Jena.

Hts, W. 1865 Beobachtungen über den Bau des Säugethier-Eierstockes. Arch. f. mikr. Anat., Bd. 1, S. 151 .

1868 Untersuchungen über die erste Anlage des Wirbelthierleibes. Leipzig. (Quoted from (iasser and Graf Spee.)

Konluskw, A. 1884 Grundriss der Entwieklungsgesehichte des Mensehen und der höleren Tiere, 2. Aufl. Leipzig.

KowAlewsky, R. 1875 Die Bildung der Urogenitalanlage (des Wolff 'sehen Ganges) bei Hühnerembryonem, Arb. a. d. Tal. d. mediz. Fak. Warschaw, II. 2. (Reviewed in Jahresb. über d. Frtsch. d. Anat. u. Phys, von IIoffmann-Schwalbe, Bd. 4, Abth. 2, S. 448.)

MacCallum, J. B. 1902 Notes on the Wolffian body of higher mammals. Am. Jour. Anat, vol. 1, p. 245.

MeYer, H. 1890 Die Fntwieklung der Urnieren beim Mensehen. Areh. $f$. mikr. Anat., Bd. 36, S. 138. 
Minalkovicz, G. 1885 Lntersuchungen über die Entwickelung des Harn- und Gesehlechtsapparates der Amnioten. Int. Monatsch. f. Anat. u. Hist., Bd. 2, S. 41 .

Renson, G. 1883 Recherches sur le rein céphalique et le corps de Wolff ehez les oiscaux ct les mammifères. Arel. f. mikr. Anat., Bd. 22, א. 599.

Rositr, W. 1873 Über den Bau und die Entwicklung des Eierstockes und des Wolff'sclen Gangos. Areh. f. mikr. Anat., Bd. 10, S. 200 .

SEDGWICT, H. 1881 On the early development of the anterior part of the Wolfian duct and body in the chick together with some remarks ou the excretory system of the vertebrates. Quart. Journ. of Micr. Sc., vol. 21, p. 432.

SPEk, GRAF F. 1883 Über direete Beteiligung des Ektodems an der Bildung der Urnieren-anlage des Meerschweinchens. Arch. f. mikr. Anat. u. Entw., S. 89.

WALDEYER, W. 1870 Fierstock und Fi. Leipzig. 